\title{
Original article / Article original \\ General unknown screening of xenobiotics: the contribution of an acidic extraction
}

\section{Recherche large de xénobiotique : contribution de l'extraction acide}

\author{
C. Richeval` ${ }^{\star}$ J.-F. Wiart, L. Humbert, M. Shbair, M. Lhermitte
}

Université Lille Nord de France, Laboratoire de Toxicologie Centre de Biologie Pathologie Génétique, Avenue du Professeur Jules Leclercq, 59037 Lille, France

\begin{abstract}
Objectives: Although general unknown screening (GUS) is often used to detect and identify exogenous compounds in biological matrices, some compounds are not detected for two main reasons: first the method carried out for the extraction, secondly, the lack of sensitivity in the detection of the unknown molecules. The aim of this study was to improve the detection, using an acidic extraction procedure and a MRM mode $\left(\mathrm{ES}^{+}\right.$or $\left.\mathrm{ES}^{-}\right)$. Methods: Blank sera were spiked with 42 substances, not detected in GUS. $1 \mathrm{~mL}$ was extracted after addition of internal standards and $500 \mu \mathrm{L}$ of acetate buffer by $3 \mathrm{~mL}$ of organic extraction solution (dichloromethane: ether: hexane: isoamyl alcohol; 30:50:20:0.5, v/v). Basic extraction was also carried out by substituting the sodium acetate buffer with saturated borate buffer. The extracts were analysed by UPLC-MS-MS, using MRM mode (ES ${ }^{+}$or ES ${ }^{-}$). Results: All the non detected substances by the GUS method were indentified in this study, 25 in $\mathrm{ES}^{+}$mode and 17 in $\mathrm{ES}^{-}$mode. Extraction yield was between 9 and 104\%, and upper, compared to that after basic extraction. Conclusion: A rapid, sensitive and selective method using positive or negative MRM mode, with a triple quadrupole mass spectrometer and a simple acidic liquidliquid extraction allows to identify, confirm and quantify 42 substances (drugs and pesticides) not detected by a routine GUS method.
\end{abstract}

Key words: General unknown screening, acidic extraction, MRM mode detection

Résumé - Objectifs : Bien que le screening large soit souvent utilisé pour détecter et identifier les composés exogènes dans les matrices biologiques, certains composés ne sont pas détectés pour deux raisons principales : une méthode d'extraction utilisée non adaptée et un manque de sensibilité dans la détection pour les composés inconnus. Le but de cette étude a été d'améliorer la détection en utilisant une méthode d'extraction acide et le mode MRM (ES ${ }^{+}$ou $\left.\mathrm{ES}^{-}\right)$. Méthodes : Le blanc sérum a été surchargé avec 42 substances, non détectées par le screening de recherche large. $1 \mathrm{~mL}$ d'échantillon en présence d'étalons internes a été extrait avec $500 \mu \mathrm{L}$ de tampon acétate et $3 \mathrm{~mL}$ d'un mélange de solvants (dichlorométhane/ether/hexane/alcool isoamylique 30/50/20/0,5 v/v). L'extraction basique a également été évaluée en substituant le tampon acétate par du tampon borate. Les extraits sont analysés par UPLC-MS/MS, en utilisant le mode MRM ( $\mathrm{ES}^{+}$ou $\left.\mathrm{ES}^{-}\right)$. Résultats : Tous les composés non détectés par la méthode screening large ont été identifiés dans cette étude, 25 en mode $\mathrm{ES}^{+}$et 17 en mode $\mathrm{ES}^{-}$. Les rendements d'extraction étaient compris entre 9 et $104 \%$, et supérieurs à ceux obtenus après extraction basique. Conclusion : Une méthode rapide, sensible et spécifique utilisant le mode $\mathrm{MRM}$ en $\mathrm{ES}^{+}$ou $\mathrm{ES}^{-}$, et une simple extraction liquide-liquide à $\mathrm{pH}$ acide, permet d'identifier, de confirmer et de quantifier 42 composés (médicaments et pesticides) non détectés par la méthode de screening de routine.

Mots clés : Screening large de recherche des xénobiotiques, extraction acide, détection en mode MRM

Received 28 juin 2011, accepted after revision 2 septembre 2011

Published online 17 october 2011

\section{Introduction}

General unknown screening (GUS) is often used to detect and identify exogenous compounds in various biological ma-

\footnotetext{
^Correspondence: C. Richeval, camille.richeval@chru-lille.fr
}

trices (blood, urine or hair) in clinical and forensic toxicology, but with very different concentrations depending on the circumstances of poisoning (acute poisoning or chemical submission). The screening of xenobiotics can be carried out using untargeted separative methods and identification by GC-MS 
[1-3], GC-MS/MS [4-6], HPLC-DAD[7], HPLC/MS [8, 9], HPCL-MS/MS [10, 11], UPLC-MS [12], or UPLC-MS/MS [13]. In these screenings, the identity of the compounds is established by comparison of the obtained spectra (UV or mass/z) with reference spectra from commercial or in-house made libraries.

Nowadays, LC-MS (-MS) or UPLC-MS (-MS) is used routinely in the framework of analysis prescribed in clinical or forensic toxicology, because this technology allows the detection of the largest number of compounds. However, some compounds are not detected in GUS, for two main reasons. The first is the method carried out for the extraction of the unknown molecules contained in the biological matrix; the second reason is the lack of sensitivity in the detection for these molecules. For this last point, Multi Reaction Monitoring (MRM) mode in mass spectrometry improves the detection limit of these compounds, but this acquisition only allows targeted research due to a setting of many specific MRM transitions.

Another point, the sample preparation (extraction from a biological matrix) is a step that must be evaluated and controlled, for obtaining the best limit of detection. A lot of molecules have been detected, because the authors focused on one substance [14], or on a given therapeutic class, such as benzodiazepines [15]. It is clear that a sample preparation method which is specifically directed toward a molecule or a group of similar molecules will be the most efficient and probably more sensitive, but will require other extractions to detect other molecules, potentially present. The repetition of extractions is laborious and requires larger sample.

A screening of xenobiotics by UPLC-MS using in-source fragmentation at increasing cone voltages has been described [13]. The xenobiotics were detected after mixture of two extractions one under acidic conditions, the other under basic conditions, by ionization in both $\mathrm{ES}^{+}$and $\mathrm{ES}^{-}$. In this work, some xenobiotics (drugs or pesticides) were not detectable probably due to the sample preparation or a lack of sensitivity of the mass spectrometer. The aim of the study was to improve the detection of these compounds; an acidic extraction protocol was here investigated for the detection of these molecules in blood and compared to a basic extraction. MRM mode using $\mathrm{ES}^{+}$or $\mathrm{ES}^{-}$was applied in order to improve detection of the different compounds.

\section{Materials and methods}

\subsection{Standards and reagents}

HPLC-grade methanol and acetonitrile were from Carlo Erba (Val de Reuil, France) and from JT Baker (France), respectively. Ammonium formate and formic acid were obtained from Sigma-Aldrich (Saint Quentin Fallavier, France). Deionized water (Versol ${ }^{\circledR}$ was obtained from Aguettant, (France). All remaining organic solvents and reagents were of analytical grade and obtained from the suppliers indicated: dichloromethane (Carlo Erba, France); diethylether (Panreac, France); hexane (Sharlau, France) and isoamyl alcohol (Merck, France).

Drug substances were supplied by various pharmaceutical companies. Individual stock solutions of the standard com- pounds were prepared in methanol at $1 \mathrm{~g} / \mathrm{L}$; these were kept at $-20{ }^{\circ} \mathrm{C}$ until use.

Methylclonazepam and $\beta$-hydroxy ethyl theophylline were used as internal standards and were obtained from Roche (France) and Sigma-Aldrich, respectively. A mixed stock solution (IS mix) was prepared in methanol at 1.25 and $16 \mathrm{mg} / \mathrm{L}$, respectively, and stored at $-20^{\circ} \mathrm{C}$ until analysis.

\subsection{Biological specimens}

Blank human serum was obtained from EFS (Etablissement Français du Sang Lille, France).

\subsection{Liquid chromatography conditions}

The chromatographic system comprised an Acquity UPLC (Waters Corporation, MA, USA). Analytes were separated using an Acquity UPLC HSS $\mathrm{C}_{18}, 2.1 \times 150 \mathrm{~mm}, 1.8 \mu \mathrm{m}$ column (Waters Corporation, MA, USA) maintained at $50{ }^{\circ} \mathrm{C}$. The mobile phase was a binary mixture of formate buffer $5 \mathrm{mM}$ pH 3.0, adjusted with formic acid (A) and acetonitrile containing $0.1 \%$ formic acid (B) at a flow rate of $400 \mu \mathrm{L} / \mathrm{min}$ (generating a typical back-pressure of $\sim 9000 \mathrm{psi})(0 \mathrm{~min} .=87 \% \mathrm{~A}$; $6-7 \mathrm{~min}=5 \% \mathrm{~A} ; 7.25-10 \mathrm{~min}=87 \% \mathrm{~A})$. An injection volume of $15 \mu \mathrm{L}$ was used throughout.

\subsection{Mass spectrometry conditions}

Detection was performed using a Waters ${ }^{\circledR}$ TQ Detector, tandem quadrupole mass spectrometer (Waters Corporation, MA, USA) equipped with a Z-Spray ${ }^{\mathrm{TM}}$ source and ES probe. The instrument was controlled using Waters MassLynx ${ }^{\mathrm{TM}} \mathrm{v} 4.1$. Ionization was performed in $\mathrm{ES}^{+}$and in $\mathrm{ES}^{-}$. Source conditions were as follows: source temperature was maintained at $150{ }^{\circ} \mathrm{C}$; capillary voltage: $1000 \mathrm{~V}$; extractor cone: $3 \mathrm{~V}$; cone gas flow rate: $50 \mathrm{~L} / \mathrm{h}$; desolvation gas flow rate and temperature: $650 \mathrm{~L} / \mathrm{h}$ and $350{ }^{\circ} \mathrm{C}$, respectively.

Infusions were performed at $10 \mu \mathrm{L} / \mathrm{min}$ with variations of the cone voltage, energies of accelerations for optimisation.

For each compound, the MRM transitions, cone voltage and collision energy are indicated in Table I.

\subsection{Preparation of the solutions}

Working solutions of the drugs or pesticides of interest were prepared by dilution of the stock solution with the mobile phase to obtain a concentration of $1000 \mathrm{ng} / \mathrm{mL}$. Small volumes were analysed in two separate infusion analyses; one in $\mathrm{ES}^{+}$and one in $\mathrm{ES}^{-}$to optimize and obtain two transitions MRM (Table I).

\subsection{Data processing}

All data were processed using the QuanLynx application manager (Waters Corporation, MA, USA). This software permits the integration of MRM peaks at specific retention times and the calculation of their areas. 


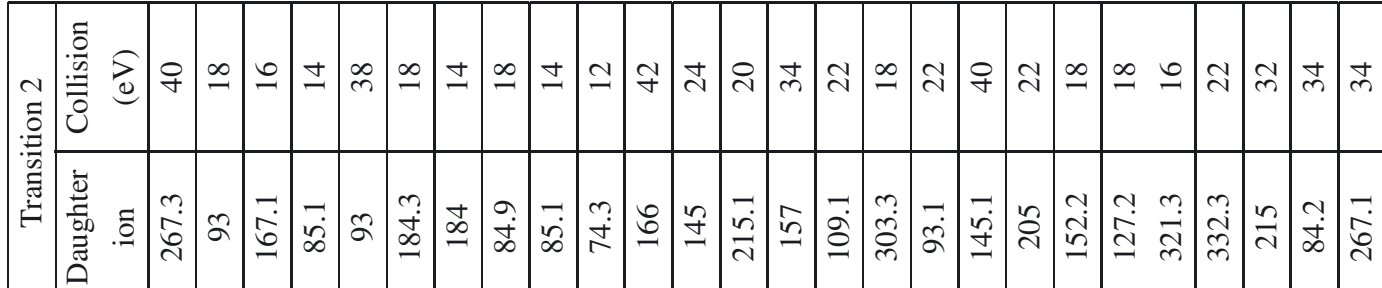

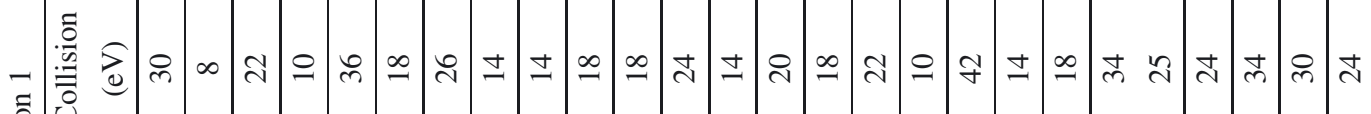

:

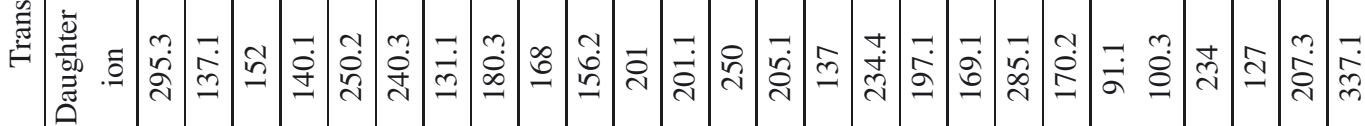

\begin{tabular}{|c|c|c|c|c|c|c|c|c|c|c|c|c|c|c|c|c|c|c|c|c|c|}
\hline ठ் & q & $\circ:$ & $\approx n$ & $\approx 4$ & $i n$ & $\tilde{n} \mid \approx$ & i & $\approx$ & $\approx$ & \begin{tabular}{l|l}
8 & $\infty$
\end{tabular} & $0 \approx$ & $\approx$ & \begin{tabular}{l|l}
$m$ & $n$ \\
$m$
\end{tabular} & 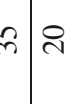 & 8 & $m$ & 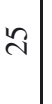 & $\dot{m} \stackrel{n}{n}$ & 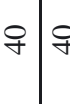 & 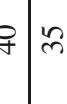 & fr \\
\hline $\begin{array}{l}\bar{n} \\
\bar{I}\end{array}$ & + & 1 & + & 1 & 1 & ++ & I & I & + & +1 & + & 1 & 1 & +1 & 1 & 1 & + & ++ & +1 & + & + \\
\hline 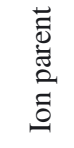 & $\overrightarrow{\tilde{m}}$ & $\overrightarrow{2}$ & 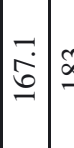 & $\stackrel{\infty}{\infty}$ & 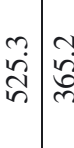 & 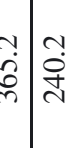 & ปิ & 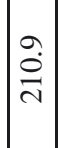 & $\vec{i}$ & 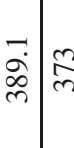 & 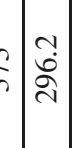 & $\underset{\sim}{\stackrel{+}{\sim}}$ & $\hat{\Xi}$ & 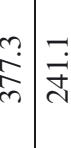 & 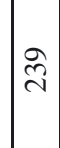 & $\begin{array}{l}m \\
\grave{2} \\
\tilde{m}\end{array}$ & $\overrightarrow{\vec{\delta}}$ & 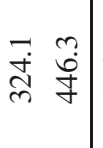 & 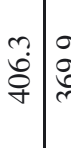 & 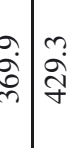 & \\
\hline
\end{tabular}

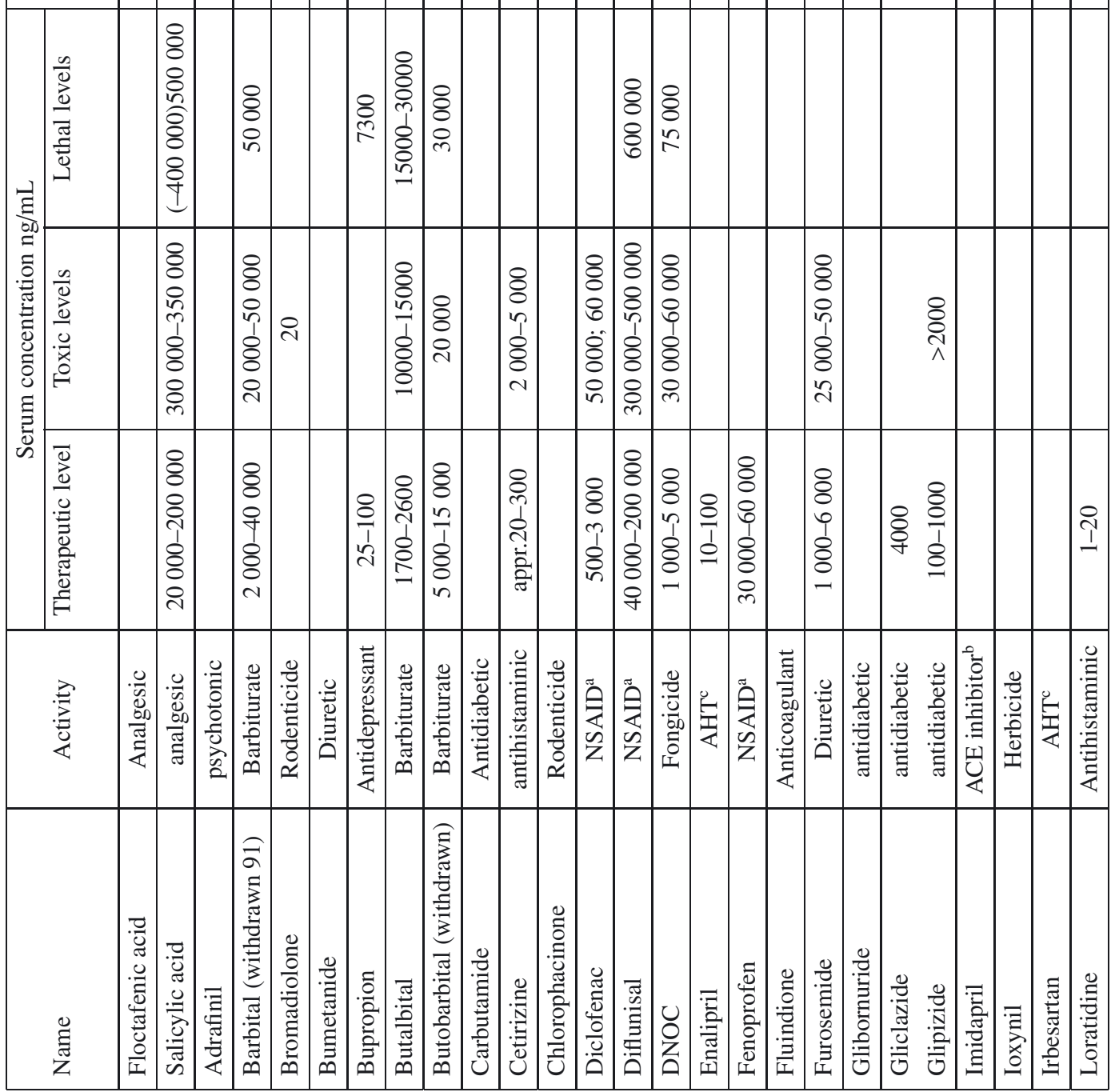




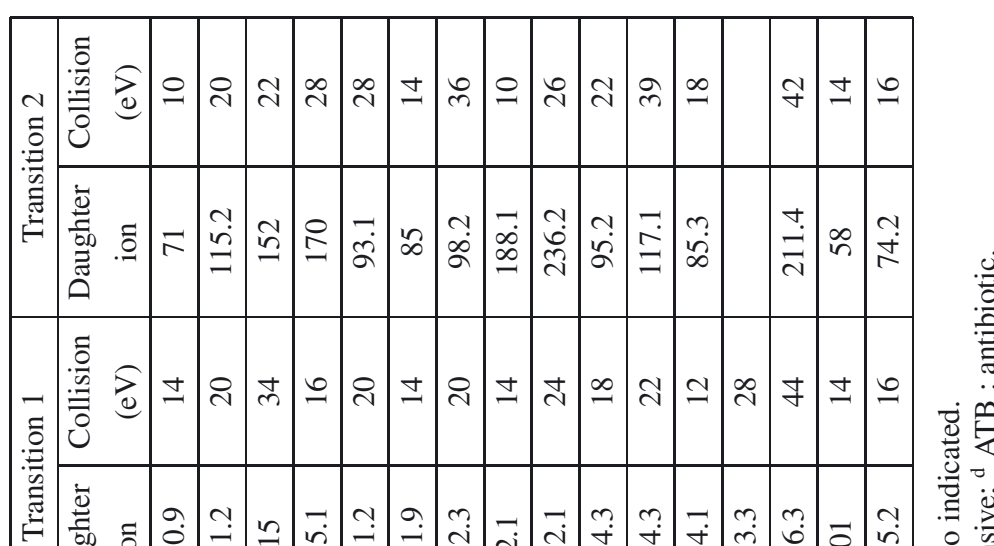

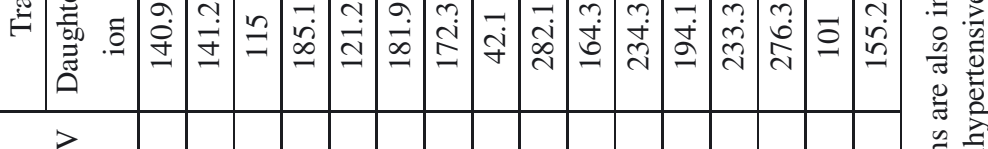

j̃

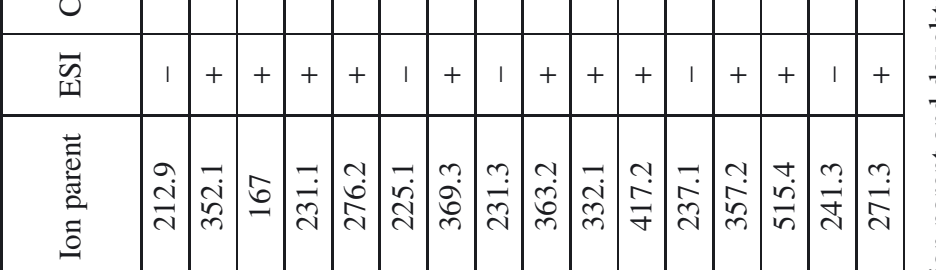

莺焉

\begin{tabular}{|c|c|c|c|c|c|c|c|c|c|c|c|c|c|}
\hline \multirow{3}{*}{ 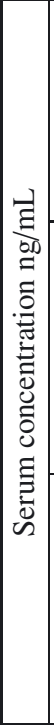 } & 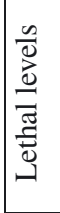 & & & & $\begin{array}{c}8 \\
8 \\
1 \\
1 \\
1 \\
8 \\
8 \\
n\end{array}$ & & 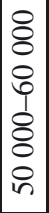 & & & $\begin{array}{l}8 \\
8 \\
1 \\
\wedge\end{array}$ & & $\begin{array}{l}8 \\
8 \\
12 \\
1 \\
8 \\
8 \\
0\end{array}$ & $\begin{array}{l}8 \\
8 \\
8 \\
8 \\
0\end{array}$ \\
\hline & 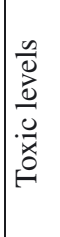 & & & $\begin{array}{l}8 \\
8 \\
8 \\
8 \\
+ \\
8 \\
8 \\
8 \\
8 \\
ن\end{array}$ & $\mid \begin{array}{l}8 \\
8 \\
\circ \\
1 \\
8 \\
8 \\
0\end{array}$ & & 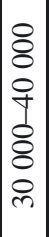 & $\begin{array}{l}8 \\
8 \\
\pm\end{array}$ & & 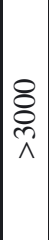 & & $\begin{array}{l}8 \\
8 \\
0 \\
0\end{array}$ & $\begin{array}{l}8 \\
8 \\
8 \\
8 \\
1 \\
8 \\
8 \\
8 \\
8 \\
+\end{array}$ \\
\hline & 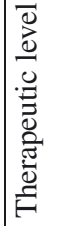 & $\left|\begin{array}{l}8 \\
\delta \\
T \\
1 \\
\delta \\
f\end{array}\right|$ & \begin{tabular}{|l|}
8 \\
8 \\
0 \\
0 \\
8 \\
0 \\
$\sim$
\end{tabular} & $\begin{array}{l}8 \\
8 \\
8 \\
8 \\
1 \\
8 \\
8 \\
8 \\
ن\end{array}$ & $\mid \begin{array}{l}8 \\
8 \\
0 \\
1 \\
8 \\
8 \\
-\end{array}$ & $\begin{array}{l}0 \\
\frac{n}{1} \\
\frac{1}{2} \\
\infty\end{array}$ & $\begin{array}{l}8 \\
8 \\
0 \\
0 \\
1 \\
8 \\
8 \\
0 \\
0\end{array}$ & $\mid \begin{array}{l}8 \\
8 \\
0 \\
1 \\
8 \\
8 \\
\text { v }\end{array}$ & 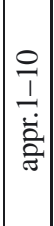 & 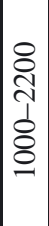 & $\begin{array}{l}8 \\
8 \\
0 \\
1 \\
8 \\
8 \\
-\end{array}$ & $\begin{array}{l}8 \\
8 \\
n \\
8 \\
8 \\
-\end{array}$ & $\begin{array}{l}8 \\
8 \\
8 \\
8 \\
1 \\
8 \\
8 \\
8 \\
0\end{array}$ \\
\hline
\end{tabular}

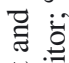

营 동 
Table II. Yield of extraction after acidic or basic extraction.

\begin{tabular}{|c|c|c|c|}
\hline \multirow{2}{*}{ Name } & \multicolumn{2}{|c|}{ Extraction yield \% } & \multirow{2}{*}{$\begin{array}{c}\text { Estimated LOD }(\mathrm{ng} / \mathrm{mL}) \\
\text { after acidic } \\
\text { extraction }\end{array}$} \\
\hline & Acetate buffer & Borate buffer & \\
\hline Floctafenic acid & $61 \%$ & $0 \%$ & 5 \\
\hline Salicylic acid & $68 \%$ & $0 \%$ & 191 \\
\hline Adrafinil & $57 \%$ & $0 \%$ & 1100 \\
\hline Barbital (withdrawn 91) & $54 \%$ & $29 \%$ & 1000 \\
\hline Bromadiolone & $83 \%$ & $33 \%$ & 50 \\
\hline Bumetanide & $62 \%$ & $0 \%$ & 50 \\
\hline Bupropion & $77 \%$ & $30 \%$ & 10 \\
\hline Butalbital & $54 \%$ & $30 \%$ & 5000 \\
\hline Butobarbital & $63 \%$ & $70 \%$ & 10300 \\
\hline Carbutamide & $54 \%$ & $0 \%$ & 10 \\
\hline Cetirizine & $61 \%$ & $1 \%$ & 3 \\
\hline Chlorophacinone & $47 \%$ & $11 \%$ & 49 \\
\hline Diclofenac & $61 \%$ & $10 \%$ & 32 \\
\hline Diflunisal & $80 \%$ & $10 \%$ & 9000 \\
\hline DNOC & $80 \%$ & $3 \%$ & 49 \\
\hline Enalipril & $58 \%$ & $0 \%$ & 0.8 \\
\hline Fenoprofen & $100 \%$ & $0 \%$ & 297 \\
\hline Fluindione & $89 \%$ & $0 \%$ & 5000 \\
\hline Furosemide & $70 \%$ & $0 \%$ & 608 \\
\hline Glibornuride & $73 \%$ & $15 \%$ & 5 \\
\hline Gliclazide & $86 \%$ & $21 \%$ & 4 \\
\hline Glipizide & $71 \%$ & $3 \%$ & 5 \\
\hline Imidapril & $104 \%$ & $0 \%$ & 900 \\
\hline Ioxynil & $85 \%$ & $0 \%$ & 49 \\
\hline Irbesartan & $79 \%$ & $0 \%$ & 0.5 \\
\hline Loratidine & $68 \%$ & $50 \%$ & 0.2 \\
\hline Mecoprop & $87 \%$ & $0 \%$ & 5000 \\
\hline Meloxicam & $56 \%$ & $0 \%$ & 21 \\
\hline Modafinil Acid & $101 \%$ & $0 \%$ & 310 \\
\hline Naproxen & $9 \%$ & $0 \%$ & 1088 \\
\hline Nifuroxazide & $53 \%$ & $19 \%$ & 0.5 \\
\hline Pentobarbital/Amobarbital & $83 \%$ & $79 \%$ & 3728 \\
\hline Perindopril & $67 \%$ & $0 \%$ & 10 \\
\hline Phenobarbital & $68 \%$ & $50 \%$ & 1908 \\
\hline Piretanide & $66 \%$ & $1 \%$ & 5 \\
\hline Piroxicam & $95 \%$ & $3 \%$ & 6 \\
\hline Ramipril & $65 \%$ & $0 \%$ & 0.9 \\
\hline Secobarbital & $33 \%$ & $50 \%$ & 2970 \\
\hline Sulindac & $93 \%$ & $2 \%$ & 6 \\
\hline Telmisartan & $67 \%$ & $10 \%$ & 50 \\
\hline Thiopental & $44 \%$ & $27 \%$ & 1880 \\
\hline Tolbutamide & $55 \%$ & $9 \%$ & 1008 \\
\hline
\end{tabular}

\subsection{Biological sample preparation}

Blank sera were spiked with the substances approximately at high therapeutic concentrations, when these concentrations were known. When the therapeutic concentrations of the drug were unknown, or when the compound was a pesticide, concentration less than $5000 \mathrm{ng} / \mathrm{mL}$ was tested. Blank serum and spiked serum were prepared by a liquid- liquid extraction (LLE) by acidic extraction. One milliliter of biological sample, $100 \mu \mathrm{L}$ of the IS mix and $500 \mu \mathrm{L}$ sodium acetate buffer $(1 \mathrm{M}$, $\mathrm{pH} 3.5$ ) were added to a $10 \mathrm{~mL}$ Kimble tube and mixed. Samples were extracted by the addition of $3 \mathrm{~mL}$ organic extraction solution (dichloromethane: ether: hexane: isoamyl alcohol; 30:50:20:0.5, v/v). Samples were vortex-mixed for $2 \mathrm{~min}$ before centrifugation at $3000 \times \mathrm{g}$ for $5 \mathrm{~min}$. The upper, organic layer was transferred to a clean vial.

A basic extraction was also carried out using the same procedure, by substituting the sodium acetate buffer with a saturated borate buffer ( $\mathrm{pH} 9.0)$

The supernatant was evaporated under nitrogen at $60{ }^{\circ} \mathrm{C}$. Dried extracts were reconstituted in $100 \mu \mathrm{L}$ of mobile phase and vortex-mixed for 2 min before analysis.

A limit of detection has been estimated, using the highest therapeutic concentration or this last concentration by dilution $1: 10$ or $1: 100$. For substances for which the therapeutic concentrations were unknown and for the pesticides, an arbitrary concentration was first tested, and then diluted 1:10 and 1:100. 


\section{Results}

Table II indicates the 42 tested xenobiotics. For each compound, the therapeutic, toxic and lethal concentrations (when known), the mode of ionization and the chosen transitions for the identification of drugs are described. Twenty five substances were detected in $\mathrm{ES}^{+}$mode and 17 in $\mathrm{ES}^{-}$mode.

The yield of extraction was estimated after extraction in acidic (acetate buffer) or basic (borate buffer) condition. The results show clearly a better extraction using acetate buffer (Table II).

A limit of detection has been estimated, permitting the detection of all the studied compounds and the measurement of low, detectable concentrations for some compounds (Table II).

\section{Discussion}

Several general unknown screenings have been described for the detections of xenobiotics, but often the analytical protocol targeted a specific pharmacological class of drugs [16-18] or pesticides $[6,8]$.

In our original, systematic GUS procedure using a double extraction (basic and acidic), some substances were not detected [13]. Extraction of the substances was then carried out in acid and basic condition. The sensitivity of the detection has been increased by using MRM mode of detection, either in positive or negative mode. In this way, all the molecules could be detected, using only the acidic, at least at therapeutic concentrations (or less) for the drugs. Therefore, the screening described by Humbert et al. [13] is used for the GUS, and an acidic extraction is also carried out for those undetectable molecules, with detection by MRM mode. The two protocols are rapid and with the use of UPLC-MS-MS, the results are obtained in about $15 \mathrm{~min}$ for the routine procedure and $10 \mathrm{~min}$ in MRM mode for the acidic procedure.

\section{Conclusion}

We have developed a rapid, sensitive and selective UPLCMS/MS method using a positive or negative MRM mode, with a triple quadruple mass spectrometer and a simple acidic liquid-liquid extraction with small sample size to identify, confirm and quantify 42 substances (drugs and pesticides) that were not detected by the routine GUS method used in our laboratory.

Conflicts of interest. The authors declare that there are no conflicts of interest.

\section{References}

1. Costello CE, Hertz HS, Sakai I, Biemann K. Routine use of a flexible gas chromatograph-mass spectrometer-computer system to identify drugs and their metabolites in body fluids of overdose victims. Clin Chem. 1974; 20: 255-265.

2. Neill GP, Davies NW, McLean S. Automated screening procedure using gas chromatography-mass spectrometry for identification of drugs after their extraction from biological samples, J Chromatogr. 1991; 565: 207-224.
3. Meyer MR, Peters FT, Maurer HH. Automated mass spectral deconvolution and identification system for GC-MS screening for drugs, poisons, and metabolites in urine. Clin Chem. 2010; 56: $575-584$.

4. Uhl M. Determination of drugs in hair using GC/MS/MS. Forensic Sci Int. 1997; 84: 281-294.

5. Kintz P, Villain M, Dumestre V, Cirimele V. Evidence of addiction by anesthesiologists as documented by hair analysis. Forensic Sci Int. 2005; 153: 81-84.

6. Wong JW, Zhang K, Tech K, Hayward DG, Makovi CM, Krynitsky AJ, Schenck FJ, Banerjee K, Dasgupta S, Brown D. Multiresidue pesticide analysis in fresh produce by capillary gas chromatography-mass spectrometry/selective ion monitoring (GC-MS/SIM) and -tandem mass spectrometry (GCMS/MS) J Agric Food Chem. 2010; 58: 5868-5883.

7. Pragst F, Herzler M, Erxleben BT. Systematic toxicological analysis by high-performance liquid chromatography with diode array detection (HPLC-DAD). Clin Chem Lab Med. 2004; 42: $1325-1340$.

8. Dulaurent S, Moesch C, Marquet P, Gaulier JM, Lachâtre G. Screening of pesticides in blood with liquid chromatographylinear ion trap mass spectrometry. Anal Bioanal Chem. 2010; 396: 2235-2249.

9. Sauvage FL, Picard N, Saint-Marcoux F, Gaulier JM, Lachâtre G, Marquet P. General unknown screening procedure for the characterization of human drug metabolites in forensic toxicology: applications and constraints. J Sep Sci. 2009; 32: 3074-3083.

10. Dresen S, Ferreirós N, Gnann H, Zimmermann R, Weinmann W. Detection and identification of 700 drugs by multi-target screening with a 3200 Q TRAP LC-MS/MS system and library searching. Anal Bioanal Chem. 2010; 396: 2425-2434.

11. Gonzalez O, Alonso RM, Ferreirós N, Weinmann W, Zimmermann R, Dresen S. Development of an LC-MS/MS method for the quantitation of 55 compounds prescribed in combined cardiovascular therapy J Chromatogr B Analyt Technol Biomed Life Sci. 2011; 879: 243-252.

12. Wren SA, Tchelitcheff P. UPLC/MS for the identification of betablockers, J Pharm Biomed Anal. 2006; 40: 571-580.

13. Humbert L, Grisel F, Richeval C, Lhermitte M. Screening of xenobiotics by ultra-performance liquid chromatography-mass spectrometry using in-source fragmentation at increasing cone voltages: library constitution and an evaluation of spectral stability. J Anal Toxicol. 2010; 34: 571-580.

14. Tracqui A, Kintz P, Mangin P. HPLC/MS determination of buprenorphine and norbuprenorphine in biological fluids and hair samples J Forensic Sci. 1997; 42: 111-114.

15. Kintz P, Villain M, Concheiro M, Cirimele V. Screening and confirmatory method for benzodiazepines and hypnotics in oral fluid by LC-MS/MS. Forensic Sci Int. 2005; 150: 213-220.

16. Beyer J, Bierl A, Peters FT, Maurer HH. Screening procedure for detection of diuretics and uricosurics and/or their metabolites in human urine using gas chromatography-mass spectrometry after extractive methylation. Ther Drug Monit 2005; 27: 509520.

17. Simonsen KW, Steentoft A, Buck M, Hansen L, Linnet K. Screening and quantitative determination of twelve acidic and neutral pharmaceuticals in whole blood by liquid-liquid extraction and liquid chromatography-tandem mass spectrometry. J Anal Toxicol. 2010; 34: 367-373.

18. Mandrioli R, Mercolini L, Lateana D, Boncompagni G, Raggi MA. Analysis of risperidone and 9-hydroxyrisperidone in human plasma, urine and saliva by MEPS-LC-UV. J Chromatogr B Analyt Technol Biomed Life Sci. 2011; 879: 167-173. 